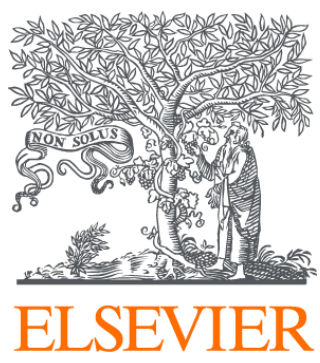

Since January 2020 Elsevier has created a COVID-19 resource centre with free information in English and Mandarin on the novel coronavirus COVID-

19. The COVID-19 resource centre is hosted on Elsevier Connect, the company's public news and information website.

Elsevier hereby grants permission to make all its COVID-19-related research that is available on the COVID-19 resource centre - including this research content - immediately available in PubMed Central and other publicly funded repositories, such as the WHO COVID database with rights for unrestricted research re-use and analyses in any form or by any means with acknowledgement of the original source. These permissions are granted for free by Elsevier for as long as the COVID-19 resource centre remains active. 
justifies its clinical testing in patients with SARS.

*J Cinatl, P Chandra, H Rabenau, $H$ W Doerr

Institute of Medical Virology, Frankfurt University Medical School, D-60596 Frankfurt, Germany

(e-mail: cinatı@em.uni-frankfurt.de)

1 Der SD, Zhou A, Williams BR

Silverman RH. Identification of genes

differentially regulated by interferon $\alpha, \beta$ or $\gamma$ using oligonucleotide arrays. Proc natl acad Sci USA 1998; 95: 15623-28.

2 Zhao Z, Zhang F, Xu M, et al. Description and clinical treatment of an early outbreak of severe acute respiratory syndrome

(SARS) in Guangzhou, PR China.

f Med Microbiol 2003; 52: 715-20.

Sir-The results of $\mathrm{J}$ Cinatl and colleagues ${ }^{1}$ show that interferon beta is effective against SARS-CoV-a membrane-enclosed RNA virus ${ }^{2}$ - in vitro, when used either alone or in combination with other antiviral drugs.

Their results concur with our beliefs that interferon, with its broadspectrum antiviral activity against RNA viruses, might be useful in the treatment of SARS, either as a monotherapy or plus ribavirin.

However, the findings of Ozes and co-workers ${ }^{3}$ show that the specific activity (antiviral units $/ \mathrm{mg}$ ) of recombinant human interferonconsensus 1 (IFN-Con 1 ) was ten-fold higher than that of interferon alfa-2a and interferon alfa-2b in vitro. Furthermore, IFN-Con1 increases the ability of or induces natural killer cells to kill target cells to a greater extent than does interferon alfa. ${ }^{3}$

Therefore, we suggest that IFNCon 1 and IFN-Con1 plus ribavirin are assessed as potential antiviral drugs for the treatment of SARS with the method used by Cinatl and colleagues.

*Hisashi Moriguchi, Chifumi Sato

* Division of Advanced Medical Technology and Intellectual Property Policy, Research Center for Advanced Science and Technology, University of Tokyo, Tokyo, 153-8904 Japan University of Tokyo, Tokyo, 153-8904 Japan
(HM); Department of Analytical Health
Science, Tokyo Medical and Dental University Science, Tokyo Medical and Dental University, Tokyo (CS)

(e-mail: hisashi@ip.rcast.u-tokyo.ac.jp)

1 Cinatl J, Morgenstern B, Bauer G, Chandra P, Rabenau H, Doerr HW
Treatment of SARS with human interferons. Lancet 2003; 362: 293-94.

2 Drosten C, Gunther S, Preiser W, et al. Identification of a novel coronavirus in patients with severe acute respiratory syndrome. N Engl F Med 2003; 348: 1967-76.

3 Ozes ON, Reiter Z, Klein S, Blatt LM, Taylor MW. A comparison of interferonCon1 with natural recombinant interferons-alpha: antiviral, antiproliferative, and natural killerinducing activities. F Interferon Res 1992 ; 12: 55-59.

\section{Politics and science}

Sir-In his Correspondence letter (Aug 2, p 404), ${ }^{1}$ Mark Robson criticises our incursion into politics in the pages of a scientific journal, castigating our "litany of complaints about US political decisions". ${ }^{2}$ We offer no apology for doing so, modestly continuing what we view as a virtuous tradition in public health that ranges from Virchow's advocacy ${ }^{3}$ for social reform after the typhus epidemic in upper Silesia in the 19th century to, more recently, the activities recognised by the award of Nobel Peace prizes to the International Physicians against Nuclear War and Médecins Sans Frontières.

We wrote our Commentary for two related reasons. First, the policies of the US administration, in many different areas, are having profound and damaging consequences for the health of people worldwide, including that of many Americans. Second, this administration is engaged in a wideranging series of activities that will prevent these health effects being documented adequately. Any lingering doubt that we might have been mistaken about its attitude to independent scientific research has been dispelled since we wrote our Commentary by the publication of an important report from the US House of Representatives. ${ }^{4}$ The report reveals that what we described was only the tip of the iceberg, cataloguing more than 20 areas in which the administration has sought to interfere with the scientific agenda. It also makes clear that these efforts are not unconnected; each has the effect of advancing the interests of one of two groups. For some, such as abstinence or abortion, religious right-wing constituencies support President Bush. For others, such as global warming or environmental protection, there are important economic consequences for his corporate supporters.

We believe that a core element of public health involves making the often invisible causes of population illhealth visible. That we would remain silent in the face of such threats to both population health and academic freedom would, therefore, be inconceivable. History has repeatedly shown the dangers of not speaking out until it is too late.

And should our views be published in The Lancet? We believe that a serious medical journal should examine not only the immediate, but also the underlying, causes of disease and premature death, which inevitably involve political issues. However, we also agree with the web editor of the British Medical fournal, ${ }^{5}$ who has eloquently described how many apparently apolitical decisions such as how much coverage to give to issues like bioterrorism, that are being talked up by politicians for their own reasons, are unknowingly advancing a political agenda. To concentrate on the immediate causes, while ignoring the social and political factors underlying ill health, is itself a political decision. Virchow was right when he said that "politics is nothing but medicine on a grand scale". ${ }^{3}$

* Martin McKee, Richard Coker

London School of Hygiene and Tropical Medicine, University of London, European Centre on Health of Societies in Transition, London WC1E 7HT, UK

(e-mail: martin.mckee@Ishtm.ac.uk)

1 Robson M. The place for politics. Lancet 2003; 362: 404

2 McKee M, Coker R. The dangerous rise of American exceptionalism. Lancet 2003; 361: 1579-80.

3 Taylor R, Rieger A. Medicine as social science: Rudolf Virchow on the typhus epidemic in upper Silesia. Int $\mathcal{F}$ Health Ser 1985; 15: 547-59.

4 United States House of Representatives. Committee on Government Reform: Minority Staff Special Investigations Division, August 2003. Politics and science in the Bush administration: report prepared for Rep Henry A Waxman. http://www.house.gov/reform $/ \mathrm{min} /$ politicsa ndscience/ (accessed Aug 9, 2003).

5 Delamothe T. How political should a general medical journal be? BMf 2002; 325: $1431-32$.

\section{Power shutdown and biological standards}

Sir-The August, 2003, power shutdown in vast areas of the northern parts of the USA and in Canada lasted several days. An inadvertent casualty during the shutdown might well have been the biological standards maintained in these areas.

The potency of various biological products for human and veterinary use is expressed in international units rather than in conventional units of weight. Biological activity of these products is standardised against their respective activity in a reference preparation. Samples of different reference materials are maintained at temperatures lower than $-70^{\circ} \mathrm{C} .{ }^{1}$ The contents of such ampoules maintain their biological activity when stored without temperature fluctuation.

There is every probability that the August, 2003, power shutdown involved electrical appliances used to store such preparations. If so, the 